\title{
Bartosz Smolik, Naród we współczesnej polskiej myśli nacjonalistycznej. Problematyka narodu w ujęciu głównych nurtów polskiego nacjonalizmu w latach 1989-2004
}

Wydawnictwo Księgarnia Akademicka, Kraków 2017, 408 ss.

DOI: 10.19195/1643-0328.24.13

W ciągu ostatnich lat w Polsce pojawiło się wiele opracowań, zarówno artykułów naukowych, jak i monografii, traktujących o działalności i ideach nurtu narodowego w III Rzeczypospolitej. Jedną z ostatnich książek na ten temat napisał pracownik Uniwersytetu Wrocławskiego Bartosz Smolik, który postanowił zbadać stosunek współczesnych polskich nacjonalistów do pojęcia narodu.

Szczególnie ważny wydaje się wstęp, w którym autor dokonał szczegółowego podziału nurtów nacjonalistycznych w Polsce, jak również przyporządkował im określone formacje polityczne czy środowiska. Pierwszy - neoendecki - reprezentują: Stronnictwo Narodowe „Senioralne”, Stronnictwo Narodowo-Demokratyczne, Młodzież Wszechpolska, Stronnictwo Narodowe „Szczerbiec”, pismo „Myśl Polska”. Drugi nurt — katolicko-narodowy - obejmuje: Stronnictwo Ludowo-Narodowe, Klub „Myśl dla Polski”, część osób związanych z Ligą Polskich Rodzin i radiem Maryja. Trzeci - narodowo-radykalny - to przede wszystkim: Ofensywa Narodowo-Radykalna, Front Narodowo-Radykalny, Obóz Narodowo-Radykalny czy Narodowe Odrodzenie Polski. Kolejny, czwarty - progresywistyczny - skupia Zjednoczenie Chrześcijańsko-Narodowe i Ruch Młodej Polski. Ostatni, piąty - neopogańsko-słowiański - to: Unia Społeczno-Narodowa, Stowarzyszenie na Rzecz Tradycji i Kultury „Niklot” oraz Nacjonalistyczne Stowarzyszenie „Zadruga”.

W rozdziale pierwszym Smolik poddał analizie teoretycznej pojęcia „naród” i „nacjonalizm” oraz określił, jak postrzegano te kategorie w przeszłości. Szczególnie ciekawe wydają się rozważania dotyczące elementów składowych tzw. starego i nowego nacjonalizmu występującego w początku XXI w. Ten pierwszy podkreślał znaczenie państwa narodowego, jego zwolennicy wrogo traktowali inne nacje. Korzystano przede wszystkim z rodzimych tradycji, podkreślając ważną rolę „swoich”, oryginalnych źródeł ideowych. Uznawano ważną rolę religii dla optymalnego rozwoju idei narodowej. Identyfikowano się z szeroko rozumianym nurtem prawicowym, korzystano po części z jego dorobku. Nieco inaczej jest w wypadku najważniejszych aksjomatów tzw. nacjonalizmu nowego typu. Przede wszystkim można zauważyć słabsze relacje z państwem narodowym, wrogami stają 
się elity polityczne, rodzimy establishment. Dodać do tego należy niechęć do emigrantów wyznających religię muzułmańską. Nacjonalizm ten otwiera się na idee przychodzące z zagranicy, przy ich jednoczesnym niejasnym statusie: czy novum jest ruchem prawicowym, czy lewicowym. Kolejnym ważnym elementem jest obojętność religijna nacjonalistów, często przechodząca w nastroje antyreligijne czy antyklerykalne. Ważnym punktem, który konstytuuje nacjonalizm, jest tradycja - autor słusznie poddał to pojęcie głębszej analizie, biorąc pod uwagę jej znaczenie w przeszłości, a także obecnie.

Rozdział drugi ma charakter historyczny; opisano w nim znaczenie narodu w polskiej myśli nacjonalistycznej, jego genezę, powiązania z państwem i religią, przede wszystkim katolicyzmem. Smolik wskazał, które wrogie siły stanowiły, zdaniem nacjonalistów, poważne zagrożenie dla bytu narodu. Była to głównie ekspansja polityczna Niemiec uważano, że konflikt między obydwoma narodami jest uwarunkowany obiektywnie. Kolejnym wrogiem była społeczność żydowska; tutaj jako argument podawano między innymi odmienność kulturową, niemożność asymilacji, kwestie gospodarcze. Interesującą kategorią, której autor rozprawy poświęcił dużo miejsca we fragmencie opisującym wrogów narodu, jest tzw. spiskowa teoria dziejów. W tym kontekście wymienić można decydujące o losach świata "anonimowe mocarstwo", masonerię, diasporę żydowską. Za słuszną należy uznać decyzję, aby tematy, które dotyczą narodu, a które podejmowano w okresie II wojny światowej i Polski Ludowej, znalazły się w omawianym rozdziale.

Rozdział trzeci dotyczy rozumienia pojęcia narodu wśród współczesnych polskich nacjonalistów. Podniesiono ich stosunek do katolicyzmu w sensie zarówno doktrynalnym, jak i instytucjonalnym oraz opisano, jakie znaczenie ma dla nich nie tylko przeszłość narodowa, lecz także szeroko rozumiana cywilizacja europejska. W kontekście swoich rozważań Smolik wyróżnił poszczególne aspekty konstytuujące naród, a które w większym lub mniejszym stopniu podkreślają jako ważne polscy nacjonaliści. Wymienić w tym kontekście należy historyczność, ciągłość pokoleń, prawnonaturalność, rodzinę rodzin, organicyzm, kulturę, celowość i misję, a także wspólnotę krwi. Zauważa się przy tym, że ten ostatni element pojawia się wśród polskich nacjonalistów rzadko; znaleźć go można w wypowiedziach radykałów będących pod wpływem koncepcji rasistowskich.

Ważne miejsce w omawianym rozdziale poświęcono „głównym wrogom ideowym” oraz „pozostałym wrogom narodu”. Wśród tych pierwszych wymienić należy wolnomularstwo, w niektórych wypowiedziach nacjonalistów łączone ze spiskiem żydowskim. Kolejno wymienić można kosmopolityzm, polityczną poprawność czy globalizm. Liberalizm był przez środowiska nacjonalistyczne traktowany często w sposób ambiwalentny. Autor słusznie zauważa, że wspomnianych wrogów można sklasyfikować jako „dziedziczonych”, a spośród nowych, którzy pojawili się po 1989 r., wymienić należy zarówno elity społeczno-polityczne, wywodzące się z „okrągłego stołu” i będące jego beneficjentami, jak również mniejszości seksualne czy doktrynę feministyczną.

W ostatnim, czwartym rozdziale autor zajął się takimi problemami, jak przyszłość państwa narodowego, jego suwerenność, kwestie związane z wychowaniem społeczności o charakterze narodowym. Szczególnie interesujący i zarazem ważny wydaje się fragment poświęcony narodowi w procesie globalizmu i globalizacji. Nacjonaliści traktują 
te pojęcia podejrzliwie, uważając, że są one szkodliwe dla idei, którą reprezentują. Globalizm jest często utożsamiany z ideologią. Wśród ciekawszych i bogatszych intelektualnie polskich krytyków globalizmu autor wymienia Gabriela Turowskiego - członka „Nowego Przeglądu Wszechpolskiego” i Klubu „Myśl dla Polski”; przyszłość dla niego to czas, w którym nie będzie chrześcijaństwa, dominować będą okultyzm, magia, parapsychologia czy wyznania orientalne. Innym krytykiem, związanym z „Radiem Maryja”, jest Piotr Jaroszyński; obawia się on światowej oligarchii, która będzie niezależna od państw czy praw, uważa też, że wpływ jednostki na proces rządzenia będzie iluzoryczny. Wspomnieć należy też o wizji globalizmu związanego z „Myślą Polską” Jana Engelgarda, który pisał o dwóch globalizmach: tym „mniej groźnym”, związanym z interesem narodowym, i „destrukcyjnym” kosmopolitycznym. Cenne są również badania Smolika dotyczące stosunku osób związanych z nurtem narodowym do skutków integracji europejskiej. Tutaj znowu należy odwołać się do poglądów poszczególnych działaczy, którym bliskie są idee narodowe. Rafał Broda na przykład integrację z Unią Europejską widział jako proces szkodliwy dla Polski, czyniący z niej państwo skolonizowane. Z kolei Jan Piwowarski wieszczył, iż w wyniku upadku $80 \%$ gospodarstw rolnych w Polsce kraj straci suwerenność żywnościową. W tym kontekście wymienić należy opinię bardziej wyważonego Jana Marii Jackowskiego, który stwierdzał, że strona polska bardziej skupiła się na technicznym wejściu w struktury europejskie niż na opracowaniu swoich podstawowych interesów, których należałoby, będąc we wspólnocie, bronić.

Dodatkowym, ważnym aspektem pracy jest to, że Bartosz Smolik potrafił interesujące go zagadnienia interpretować w sposób zarówno historyczny, jak i politologiczny, co musi zwiększać wartość poznawczą książki.

Wspomnieć należy też o bazie źródłowej, z której korzystał autor: sporządził on analizę ponad sześćdziesięciu tytułów prasowych oraz ponad czterdziestu szczegółowych programów partyjnych. Imponująco przedstawia się lista pism i publicystyki politycznej. Kwerendą Smolik objął również ogromną liczbę monografii i artykułów naukowych. Przejawem skrupulatności w poszukiwaniu właściwych źródeł jest dotarcie do tzw. zinów (pisma niezależne, o niskich nakładach, dystrybuowane wśród wąskiej grupy zainteresowanych).

Opracowanie Bartosza Smolika jest cenne, zwłaszcza w obliczu badań dotyczących rozwoju idei nacjonalistycznej we współczesnej Polsce. Dodatkowym walorem książki jest jasność i klarowność wywodu, o którą bardzo trudno, gdy w grę wchodzi złożoność tematu podjętego przez autora omawianej monografii. 